\title{
Financial Inclusion Measurement in the Least Developed Countries in Asia and Africa
}

\author{
Alicia Girón ${ }^{1}$ · Amirreza Kazemikhasragh ${ }^{1}$ - Antonella Francesca Cicchiello ${ }^{2}[$. \\ Eva Panetti ${ }^{3}$
}

Received: 18 August 2020 / Accepted: 14 February 2021 / Published online: 8 March 2021

(c) The Author(s) 2021

\begin{abstract}
The purpose of this paper is to examine the determinants of financial inclusion in the least developed countries in Asia and Africa. We used World Bank data to estimate the probit econometric technique in the studied countries. The results show that young people and women are groups excluded from financial inclusion and that education and income are two of the key pillars for increasing financial inclusion. Furthermore, the results reveal that a higher level of financial inclusion increases the level of official savings in countries, which in turn promotes their development. The findings of this study are beneficial for policymakers in the least developed countries to promote innovative approaches to enhance the involvement of excluded people in formal finance.
\end{abstract}

Keywords Financial inclusion · Gender · Development · financial institutions

JEL classification $\mathrm{G} 21 \cdot \mathrm{J} 16 \cdot \mathrm{O} 16 \cdot \mathrm{O} 23$

Antonella Francesca Cicchiello antonella.cicchiello@unicatt.it
Alicia Girón
alicia@unam.mx
Amirreza Kazemikhasragh
amirkazemi@outlook.com
Eva Panetti
eva.panetti@uniparthenope.it

1 University Program of Studies On Asia and Africa (PUEAA), National Autonomous University of Mexico (UNAM), Mexico City, Mexico

2 Dipartimento Di Scienze Economiche E Sociali, Università Cattolica del Sacro Cuore, Piacenza, Italy

3 Dipartimento Di Studi Aziendali E Quantitativi, Università Degli Studi Di Napoli Parthenope, Naples, Italy 


\section{Introduction}

Financial inclusion (FI) has been identified as one of the growth-enhancing factors for developing countries (Abubakar et al., 2020). Due to its multidimensional nature and the existence of various approaches in different jurisdictions, there is no universally accepted definition of financial inclusion in the financial literature (Sanderson et al., 2018). However, it can be defined in simple terms as the access and use of formal financial services by households and businesses, such as opening a bank account with a registered financial institution (Sahay et al., 2015). In broader terms, financial inclusion refers to a situation in which most of the financial services reach a sufficiently large proportion of individuals and families, granting them timely and adequate access to credit and other financial products at affordable prices (Olaniyi \& Adeoye, 2016). The development of the financial sector, together with financial integration and access to financial services, plays a critical role in improving people's livelihoods, reducing poverty and boosting economic development (Chibba, 2009; Manij, 2010). A financial system capable of serving all members of a community, especially women and the poor, can provide educational and investment opportunities for every individual; it can help people receive bank loans, have insurance coverage for various types of risks and facilitate and secure payments (Avais, 2014; Mader, 2018). Well-functioning financial systems promote the establishment of new enterprises and the growth of existing companies (Demirgüç-Kunt \& Levine, 2008), strengthen the economic empowerment and active participation in the financial system of youth, women and other vulnerable groups previously marginalised (Siddik, 2017; Hendriks, 2019). Various studies, such as Sarma and Pais (2011) and Ghosh (2013), show that economic growth and development can be achieved by increasing access to financial services for all individuals.

Today, all the countries work on financial inclusion and setting it as a priority goal. Given the increased awareness of the contribution of financial sector development to poverty reduction and economic growth, financial inclusion has been placed high on the national agendas of many developing countries, including Asia and Africa (Demirgüç-Kunt \& Klapper, 2012; Shafi \& Medabesh, 2012; Sharma \& Kukreja, 2013; Park \& Mercado, 2015).

In the African countries, financial inclusion initiatives have received support from governments and international bodies, such as the World Bank and the International Monetary Fund (IMF), which are revisiting and reviewing their developmental policies to provide the much-needed support to accelerate the economic growth of these countries (World Bank, 2014; International Monetary Fund, 2015a). Nigeria and Zimbabwe, both signatories to the Maya Declaration, ${ }^{1}$ launched their financial inclusion strategies in 2012 and 2016 respectively, setting 2020 as the target year (International Monetary Fund, 2015b; Abel et al., 2018; National Financial Inclusion Strategy, 2018). The African Development Bank (AfDB) launched the Africa Digital Financial Inclusion Facility (ADFI) in 2019, an innovative financing facility

\footnotetext{
1 The Maya Declaration is the first global set of measurable commitments aimed at promoting financial inclusion, approved in 2011 by over 90 developing and emerging economy governments.
} 
designed to accelerate digital financial inclusion across Africa and ensure access to the formal economy to millions of Africans.

Asia has made significant progress in financial inclusion. Regional discussions of the issue have intensified, and many countries have incorporated financial inclusion in their strategies to achieve inclusive growth (Loukoianova et al., 2018).

Many initiatives have been taken to promote financial inclusion in Asia over the last years. However, it remains a key challenge in the region. The significant differences across Asian countries, not only at the level of GDP per capita and population size but also at the cultural, ethnic, linguistic and religious levels, makes it difficult to bridge the gaps between rich and poor, men and women, rural and urban populations (Le et al., 2019a, b). More than one billion people within developing Asia have no access to formal financial services, such as bank accounts (only $27 \%$ of adults have an account in a formal financial institution).

Despite the efforts made, large gaps in financial inclusion remain across and within countries. Probably due to the wrong strategies to promote faster inclusion, or due to their poor implementation, most African and Asian countries have very high exclusion rates when compared with other countries (Le et al., 2019a, b; Abubakar et al., 2020). Nigeria, for example, is one of the developing nations which report a dismal position of $68 \%$ exclusion rate even after 4 years of the implementation of its strategy for financial inclusion of 2012.

Today, given the increasing use of advanced technology in financial systems, one can form a clear view of the changes in the situations among the world's least developed countries.

This paper aims to measure the degree of financial inclusion in the least developed countries in Asia and Africa by looking at factors such as ownership of a bank account in an official financial institution, use of bank credit and savings. The paper also examines whether gender influences financial inclusion and considers factors such as credit and savings in informal financial networks. ${ }^{2}$

The rest of this study is organised as follows. "Literature Review" reviews the related literature on financial inclusion. "Methodology" describes data, model and methodology. "Results" presents and discusses the empirical results. "Conclusions" concludes the study.

\section{Literature Review}

In this section, we review the literature on financial inclusion and the factors that favour or hinder its development. Following Ramji (2009), we define financial inclusion as obstacle- and cost-free access to financial services at an official financial institution.

Following the studies of Atieno (2001) and Sankaramuthukumar and Alamelu (2012), Zins and Weill (2016) used World Bank data to analyse trends among

\footnotetext{
2 The main feature of informal financial institutions is the emphasis on personal relationships, while the formal financial institution is the collaboration between a client and an official entity (Aliber, 2015).
} 
financial institutions in African countries. The authors indicate a stark divide between formal and informal institutions in the examined countries due to government intervention and increased financial costs for individuals. Widespread discrimination prevents large parts of the population in each of these countries from using formal financial systems and forces them to use only informal financial systems, a trend that widens gaps in income distribution and increases the proliferation of poverty.

Studies such as Al-Tamimi (2009), Bajtelsmit and Bernasek (1996) and Peng et al. (2007) establish that some of the most important factors for financial inclusion are the education level, income, gender and age. According to Hannig and Jansen (2010), financial inclusion in developing countries depends on income as well as factors such as social characteristics and household size. Analysing data from the World Bank, Demirgüç-Kunt and Klapper (2013) reveal that although more than half of the world's adults have a bank account at an official financial institution, the majority of account holders are located in developed countries. The results show that in some African countries, only $10 \%$ of people have a bank account at an official financial institution, and less than $5 \%$ of people save money in a formal institution.

Mzobe (2015) and Cetindamar et al. (2012) emphasise that education is a crucial factor in financial inclusion; schooling plays a significant role in people's decisions to use the services of formal institutions. Both studies additionally highlight the key role of gender in having a bank account and receiving credit from an official financial institution. The researchers indicate that gender is essential to one's credit background, one's use of financial services and the constraints that one faces in interactions with the financial system. Due to the negative impact of sexism, women in developing countries alike are more likely to use informal financial services than official options.

Abel et al. (2018) evaluate determinants of financial inclusion in Zimbabwe and find empirical evidence that it is positively related to factors such as age, education, financial literacy, income and internet connectivity. Olaniyi and Adeoye (2016) investigate the determinants of financial inclusion in Africa for the period 2005-2014 by demonstrating that per capita income, money in abundance (\% of GDP), literacy, Internet access and Islamic banking have a significant impact on the level of financial inclusion in Africa. In contrast, the authors find no evidence that domestic credit provided by the financial sector (\% of GDP), interest rates on deposits, inflation and population have any significant impacts on financial inclusion.

Using data from the global Findex database, Asuming et al. (2019) conduct a comparative analysis of financial inclusion in 31 sub-Saharan African countries. They find that individual-level factors, such as age, education, gender and wealth, as well as macroeconomic variables such as growth rate of GDP and presence of financial institutions and Business Freedom are significant predictors of financial inclusion.

In a recent study, Léon and Zins (2020) analyse whether the development of African regional foreign banks, also called Pan-African banks, influences financial inclusion of firms and households. The authors find that Pan-African bank presence increases firms' access to credit and favour financial access of the middle class by restoring confidence in banks. 
Using data of twenty Asian countries over the time period 2011-2016, Le et al. $(2019 a, b)$ investigate the key determinants of financial inclusion among Asian countries. The authors find evidence that financial inclusion is higher in countries with stronger economic growth and higher income in which people have more resources and better chances to utilise financial services. Furthermore, countries with a higher level of population literacy show higher levels of financial inclusion. Unemployment rates, on the other hand, have a negative impact on financial inclusion. Similarly, in their research on financial inclusion in China, Zhang and Posso (2019) reveal that financial inclusion is mainly hampered by older age and lower education levels. According to the authors, in fact, people with higher levels of education are more interested in obtaining credits from official financial institutions. The authors also demonstrate the presence of gender inequalities in financial inclusion and that women are more financially excluded mainly due to lack of documentation and gender discrimination.

People can also be financially excluded for religious, cultural reasons or a lack of interest or trust in financial services. In their study, Kim et al. (2018), for example, examine the role of religion in having an account, credit and savings in an official financial institution. The authors find evidence that religious discrimination represent a significant barrier to the use of financial services and that this same form of discrimination also causes differences in literacy, income and occupation. The authors also emphasise that gender is an important factor for financial inclusion and that women generally have a low degree of financial inclusion.

In this study, we analyse least developed countries in Asia and Africa and assess the degree of financial inclusion in each. Factors such as ownership of a bank account in an official financial institution, use of bank credit and savings formed the basis of our assessment, and we compared these factors with gender, education, income and other variables. Building upon previous research, we want to find out the impact gender and related factors have on financial inclusion in the countries under study.

\section{Methodology}

\section{Data}

The data used in this study were collected from the Global Findex database 2017 of the World Bank measuring financial inclusion among adults worldwide-including by gender, age and household income. The database was compiled using surveys in more than 140 developing and high-income countries and features data on access to and use of formal and informal financial services, including how people make payments, save money, borrow and manage risk and the use of mobile phones and internet technology to conduct financial transactions (Demirgüç-Kunt et al., 2018).

Drawing inspiration from recent literature (Zins \& Weill, 2016; Singareddy et al., 2019; Son et al., 2019; Demirgüç-Kunt et al., 2018), we focus on the basic principles of financial inclusion including in the analysis a set of dummy variables related to the use of official accounts and mobile accounts, the presence of informal savings, 
age, income and education. To identify the degree of financial inclusion in the selected countries, ${ }^{3}$ we run a probit regression using Stata.

\section{Model}

Following Zins and Weill's (2016), we analyse the extent of financial inclusion in the least developed countries in Asia and Africa by applying the following model:

$$
X_{i}=\alpha+\beta G_{i}+\sigma A_{i}+\varphi I_{i}+\rho E_{i}+\varepsilon_{i}
$$

where $X$ represents financial inclusion variables, $i$ represents the cross-sectional dimensions, $G$ represents gender, $A$ represents age, $I$ represents income, $E$ represents education, and $\varepsilon_{i}$ represents the error term.

We measure the level of financial inclusion through three dependent variables: (i) 'official accounts' - a dummy variable taking value of 1 if the individual owns a formal account at a financial institution, and 0 otherwise; (ii) 'formal savings' - a dummy variable taking value of 1 if the individual saved money in the past 12 months at a formal financial institution, and 0 otherwise; and (iii) 'official credit' - a dummy variable taking value of 1 if the individual has a credit on a formal financial institution, and 0 otherwise.

The independent variables of interest are the 'gender' (a dummy variable taking value 1 if the individual is a woman, and 0 otherwise), and the age of individuals measured through two variables: the age of individuals in years ('age') and the age squared ('age2'). The latter is used to capture a possible non-linear relationship between age and financial inclusion.

As Özşuca (2019), the income has been divided into five quintiles from lowest (first 20\%) to highest income (fifth 20\%). We use four dummy variables: the first $20 \%$ is a dummy variable taking value 1 if the income is in the first income quintile, and 0 otherwise, as for the other dummy variables (second $20 \%$, middle $20 \%$ and fourth 20\%). The richest quintile (fifth 20\%) is the omitted dummy variable. To measure the relationship between the level of education and financial inclusion, we use two dummy variables representing the primary and secondary education, respectively.

To measure barriers to financial inclusion, we estimate five dummy variables relating the excessive distance to the formal financial institutions 'Too far away", the 'Too expensive' costs, the 'Lack of documentation', 'Lack of trust' and 'Lack of money'.

\footnotetext{
${ }^{3}$ Least developed countries in Asia: Afghanistan, Bangladesh, Bhutan, Cambodia, East Timor, Lao PDR, Myanmar, Nepal and Yemen. Least developed countries in Africa: Angola, Benin, Burkina Faso, Burundi, Central African Republic, Chad, Comoros, Democratic Republic of Congo, Djibouti, Eritrea, Ethiopia, Gambia, Guinea, Guinea-Bissau, Lesotho, Liberia, Madagascar, Malawi, Mali, Mauritania, Mozambique, Niger, Rwanda, São Tomé and Príncipe, Senegal, Sierra Leone, Somalia, South Sudan, Sudan, Tanzania, Togo, Uganda and Zambia. We excluded these countries from our sample due to the lack of data in our database: Bhutan, East Timor, Yemen, Angola, Burundi, Comoros, Djibouti, Eritrea, Gambia, Guinea-Bissau, São Tomé and Príncipe, Somalia and Sudan.
} 
Table 1 Descriptive statistics of the variables

\begin{tabular}{|c|c|c|c|c|c|}
\hline Variable & Obs & Mean & Std. Dev & Min & Max \\
\hline Formal account & 30,200 & .378 & .4849073 & & \\
\hline Informal Saving & 30,200 & .777 & .4156458 & & \\
\hline \multicolumn{6}{|l|}{ Gender } \\
\hline Female & 30,200 & .537 & .4986285 & & \\
\hline \multicolumn{6}{|l|}{ Income } \\
\hline First $20 \%$ & 30,200 & .573 & .3854521 & & \\
\hline Second $20 \%$ & 30,200 & .177 & .3814956 & & \\
\hline Middle $20 \%$ & 30,200 & .187 & .3891345 & & \\
\hline Fourth $20 \%$ & 30,200 & .21 & .4054636 & & \\
\hline Richest $20 \%$ & 30,200 & .259 & .4381511 & & \\
\hline \multicolumn{6}{|l|}{ Education } \\
\hline Primary & 30,200 & .636 & 0.452124 & & \\
\hline Secondary & 30,200 & .359 & .4654920 & & \\
\hline Higher Educ & 30,200 & .005 & .0712285 & & \\
\hline \multicolumn{6}{|l|}{ Barriers to financial inclusion } \\
\hline Too far away & 22,439 & .73 & .4871891 & & \\
\hline Lack of documentation & 22,439 & .28 & .4199653 & & \\
\hline Lack of trust & 22,439 & .15 & .0805037 & & \\
\hline Lack of Money & 22,439 & .14 & 0.192414 & & \\
\hline Too expensive & 22,439 & .27 & .4457325 & & \\
\hline \multicolumn{6}{|l|}{ Mobile and Internet banking } \\
\hline Mobile account & 30,200 & .354 & .4783906 & & \\
\hline \multicolumn{6}{|l|}{ Age } \\
\hline Age & 30,200 & 35.01209 & 15.41773 & & \\
\hline Age2 & 30,200 & .5554836 & .4969182 & & \\
\hline
\end{tabular}

Source: Authors' elaboration on STATA output

Table 1 shows the descriptive statistics for all variables used in the selected countries. Statistics show that only $37.8 \%$ of people have formal accounts at one of the official banks or financial institutions in their countries, and only $35.4 \%$ of people have a mobile account. This is in line with the findings of Demirgüç-Kunt et al. (2018) showing poor access to official bank accounts in developing and least developed countries. More than half of the interviewees are women $(53.7 \%)$, and most of the respondents fall into the lowest income quartile (57.3\%). Low education levels appear to be a major problem in Asia and Africa. In fact, most of the respondents (63.6\%) received elementary or primary education, and $35.9 \%$ received secondary education. Only very few have received a higher education.

The main barrier to financial inclusion is represented by the excessive distance of financial institutions (73\%), followed by the lack of documentation (28\%), trust $(15 \%)$ and money $(14 \%)$. 
Table 2 Determinant of financial inclusion (robust standard errors in parentheses)
Formal Account Mobile account Informal saving

\begin{tabular}{cccc}
\hline Gender & & & \\
Female & $-0.52 * *$ & $0.46^{*}$ & $0.84 * *$ \\
& $(0.112)$ & $(0.28)$ & $(0.33)$
\end{tabular}

Income

\begin{tabular}{cccc} 
First q & $-0.31^{*}$ & $-0.02^{*}$ & $0.06^{*}$ \\
& $(0.164)$ & $(0.32)$ & $(0.31)$ \\
Second q & $-0.6^{* *}$ & $0.05^{*}$ & $0.04^{*}$ \\
& $(0.15)$ & $(0.33)$ & $(0.34)$ \\
\multirow{2}{*}{ Third q } & $-0.26^{*}$ & $0.16^{* *}$ & 0.33 \\
& $(0.15)$ & $(0.29)$ & $(0.34)$ \\
Fourth q & -0.09 & 0.24 & 0.29 \\
& $(0.14)$ & $(0.30)$ & $(0.32)$
\end{tabular}

Education

\begin{tabular}{cccc} 
NC. Sec & $0.51^{* *}$ & $0.34^{* *}$ & $-0.31^{* *}$ \\
& $(0.11)$ & $(0.29)$ & $(0.31)$ \\
COM. Sec & $1.46^{* *}$ & $0.42^{* *}$ & $-0.81^{* *}$ \\
& $(0.21)$ & $(0.37)$ & $(0.39)$ \\
\multirow{2}{*}{ Age } & $-0.05^{* *}$ & $0.11^{* *}$ & $-0.21^{* *}$ \\
& $(0.01)$ & $(0.07)$ & $(0.11)$ \\
Age2 & $-0.01^{* *}$ & 0.001 & $-0.01^{* *}$ \\
& $(0.01)$ & $(0.01)$ & $(0.01)$ \\
\hline
\end{tabular}

NC Sec not completed secondary school, COM Sec completed secondary school, Age 2 age squared in order to control the nonlinear relationship between age and dependent variable

*Significant at level 10\%; **Significant at level 5\%

\section{Results}

Table 2 presents the results and the marginal effects of the probit models of determinants of financial inclusion using three major indicators of financial inclusion: formal account, mobile account, and informal saving. Marginal effects refer to the impact of explanatory variables on the probability of financial inclusion, and we used the marginal effects of the probit model as a full vector with dummy variables for the results. This was accomplished by distinguishing the probability of the variables of financial inclusion (Asteriou \& Hall, 2015; Abdu et al., 2015).

The results of the marginal effects of the probit model show significant relations between individuals' characteristics and financial inclusion. In line with previous studies (Kairiza et al., 2017; Chen \& Divanbeigi, 2019; Atakli \& Agbenyo, 2020; Lotto, 2020), we find that women are less likely to be financially included. Being a woman reduces the probability of having an official bank account. However, being a woman increases the probability of having a mobile account and savings in an informal manner. Due to financial deprivation, women are turning to savings outside the 
formal banking and financial system, and we can therefore conclude that women in the countries under study are more likely to rely on informal sources. This confirms the results of Flory (2018) showing that informal sources are increasing in the past years.

Though gender discrimination is evident in the countries under study, Vossenberg (2013) and Meunier et al. (2017) assert that there is no significant gender gap between developed and developing countries in bank account ownership.

Our results show that age also has a relationship with financial inclusion factors, confirming the results of Susilowati and Leonnard (2019). Age has a negative and significant relation with the probability of having an official bank account and savings in an informal manner but has a positive effect on the probability of having a bank mobile account. Younger people are less likely to be financially included. Age-squared (used to capture the linear and nonlinear effects of the variable Age in the models) confirms results of Age's variable. Based on the results, it can be said that education plays an essential role in financial inclusion. As seen in the two rows that measure education, people with higher literacy levels have more access to modern banking services; the education coefficients are higher than those for income. However, education has a negative significant impact on the probability of having savings in an informal manner.

Finally, the results show that all income variables have negative effects on the probability of having formal accounts. However, they have positive effects on possibility of mobile accounts and informal savings (except for the first quintile of income which has a negative effect on mobile accounts).

Overall, we can conclude that older age, better education and high income increase men's probability to be financially included. Being younger, woman, less educated and with low income reduces the opportunity for financial inclusion.

Table 3 shows the analysis of factors associated with five barriers leading to financial exclusion.

Apart from the influence of discrimination, individuals may, for personal reasons, decide not to open an account at an official financial and banking institution. We have put together five factors to determine the reasons for foregoing financial inclusion: distance from a financial institution, high cost of financial services, lack of required documentation, lack of trust in official institutions and lack of money for savings.

The results show that women face several barriers to financial inclusion, the most important being lack of money. This is in line with Shihadeh (2018), which believes that lack of money is the most important barriers of financial exclusion.

The lack of trust, and documentation, as well as the distance to the bank and its high costs, constitute less important barriers to the financial inclusion of women. Our results confirm previous studies (see for example Choo et al., 2019), according to which male dominate culture is a main reason for women financial exclusion.

Education is positively associated only with the lack of money. This means that for individuals with better education, the only reason for being financially excluded is the lack of money. Education is negatively associated with all the other analysed barriers, showing that a better level of education could help decrease constraints to financial inclusion. 
Table 3 Determinants of barriers to financial inclusion (robust standard errors in parentheses)

\begin{tabular}{|c|c|c|c|c|c|}
\hline & Too far away & Too expensive & $\begin{array}{l}\text { Lack of } \\
\text { documentation }\end{array}$ & Lack of trust & Lack of money \\
\hline \multicolumn{6}{|l|}{ Gender } \\
\hline Female & $\begin{array}{c}-0.09 * * \\
(0.017)\end{array}$ & $\begin{array}{c}-0.48^{* *} \\
(0.02)\end{array}$ & $\begin{array}{c}-0.04 * * \\
(0.02)\end{array}$ & $\begin{array}{c}-0.13 * * \\
(0.02)\end{array}$ & $\begin{array}{l}0.01 * * \\
(0.01)\end{array}$ \\
\hline \multicolumn{6}{|l|}{ Income } \\
\hline First & $\begin{array}{c}-0.11^{* *} \\
(0.026)\end{array}$ & $\begin{array}{c}-0.05^{* *} \\
(0.027)\end{array}$ & $\begin{array}{c}-0.01 * * \\
(0.027)\end{array}$ & $\begin{array}{c}-0.15^{* *} \\
(0.03)\end{array}$ & $\begin{array}{l}0.12 * * \\
(0.02)\end{array}$ \\
\hline Second & $\begin{array}{c}-0.13 * * \\
(0.027)\end{array}$ & $\begin{array}{l}-0.1 * * \\
(0.026)\end{array}$ & $\begin{array}{c}-0.01 * * \\
(0.026)\end{array}$ & $\begin{array}{c}-0.16^{* * *} \\
(0.02)\end{array}$ & $\begin{array}{l}0.07 * * \\
(0.03)\end{array}$ \\
\hline Third & $\begin{array}{c}-0.15^{* *} \\
(0.026)\end{array}$ & $\begin{array}{c}-0.09 * * \\
(0.027)\end{array}$ & $\begin{array}{c}-0.04 * * \\
(0.026)\end{array}$ & $\begin{array}{c}-0.18 * * \\
(0.02)\end{array}$ & $\begin{array}{l}0.06 * * \\
(0.03)\end{array}$ \\
\hline Fourth & $\begin{array}{c}-0.17 * * \\
(0.027)\end{array}$ & $\begin{array}{c}-0.08 * * \\
(0.026)\end{array}$ & $\begin{array}{l}-0.01 * * \\
(0.02)\end{array}$ & $\begin{array}{c}-0.09 * * \\
(0.03)\end{array}$ & $\begin{array}{c}-0.03 * * \\
(0.03)\end{array}$ \\
\hline \multicolumn{6}{|l|}{ Education } \\
\hline NC. Sec & $\begin{array}{c}-0.27 * * \\
(0.021)\end{array}$ & $\begin{array}{l}-0.15^{* *} \\
(0.02)\end{array}$ & $\begin{array}{c}-0.31 * * \\
(0.031)\end{array}$ & $\begin{array}{c}-0.11 * * \\
(0.03)\end{array}$ & $\begin{array}{c}0.02 \\
(0.02)\end{array}$ \\
\hline COM. Sec & $\begin{array}{c}-0.16^{* *} \\
(0.07)\end{array}$ & $\begin{array}{c}-0.16^{* *} \\
(0.07)\end{array}$ & $\begin{array}{c}-0.81 * * \\
(0.039)\end{array}$ & $\begin{array}{c}-0.07 * * \\
(0.08)\end{array}$ & $\begin{array}{r}-0.07 \\
(0.08)\end{array}$ \\
\hline Age & $\begin{array}{c}-0.01 * * \\
(0.01)\end{array}$ & $\begin{array}{l}0.01 * * \\
(0.01)\end{array}$ & $\begin{array}{c}-0.21 * * \\
(0.011)\end{array}$ & $\begin{array}{c}-0.03 * * \\
(0.01)\end{array}$ & $\begin{array}{l}0.03 * * \\
(0.01)\end{array}$ \\
\hline Age2 & $\begin{array}{l}0.01 * * \\
(0.01)\end{array}$ & $\begin{array}{l}-0.01 * * \\
(0.01)\end{array}$ & $\begin{array}{l}0.01 * * \\
(0.01)\end{array}$ & $\begin{array}{l}0.01 * * \\
(0.01)\end{array}$ & $\begin{array}{c}-0.01 * * \\
(0.01)\end{array}$ \\
\hline
\end{tabular}

NC Sec not completed secondary school, COM Sec completed secondary school, Age2 age squared in order to control the nonlinear relationship between age and dependent variable

*Significant at level 10\%; **Significant at level 5\%

Lack of trust and documentation, as well as the high costs and the distance to the bank, represent barriers to financial inclusion for all income groups. Barriers to financial inclusion seem to decrease with age.

\section{Conclusions}

The results showed that the least developed countries have a low degree of financial inclusion. We know that financial inclusion can lead to development and economic growth (Sharma, 2016; Kim, 2016) due to its empowerment of women and creation of entrepreneurs. From the results, we can see the different level of financial inclusion across several categories, such as gender, age, educational level and income level. Therefore, countries can achieve greater women empowerment and gender equality by applying policies regarding financial inclusion for all individuals. The results show that gender can affect the type of savings (formal or informal savings) 
that an individual possesses, and thus, women can receive more benefits and enjoy increased access to financial services when financial approaches are adjusted.

The findings reinforce the view that policymakers and planners should target the needs of youth and women to increase financial inclusion. Research shows that gender is significant in choosing services; because women are less likely to be financially inclusive, they are more likely to use informal services, and this reduces formal savings. As Chowdhury (1994) points out, the decline in official savings leads to a slowdown in economic growth. It can be concluded that by increasing education and income, women could be more financially included. This result confirms the study of Cabeza-García et al. (2019). As technology can drive economic growth and development, this study shows that incentives to use mobile banking services increase financial inclusion levels in the studied countries.

The results of this study confirm that least developed countries can empower youth, women and other vulnerable groups traditionally marginalised, by changing their financial policies and designing new incentives to strengthen least developed countries in Asia and Africa. Policymaking can empower groups that are not financially inclusive and increase opportunities for education and income. Finally, we can deduce that informal finance and banking is not a viable method to develop and empower individuals economically.

This research could be of interest to several groups. Researchers could adopt this methodology not only for one country or group of countries but also for the provinces, states or other subdivisions within a country. More cooperation between the policymakers, private sector and regional governments could improve financial inclusion. This methodology could determine financial inclusion policies across both subnational and international borders. Stakeholders and policymakers should promote greater gender equality and maximise economic and social benefits.

Author Contribution Study conception and design (A.K and A.F.C). Acquisition of data (A.K). Analysis and interpretation of data (A.K). Drafting of manuscript (A.K., and A.F.C.). Critical revision (A.G and E.P). Project administration and supervision (E.P).

Funding Open access funding provided by Università Cattolica del Sacro Cuore within the CRUI-CARE Agreement.

Data Availability The datasets generated and/or analysed during the current study are available in the Global Findex database.

\section{Declarations}

Conflict of Interest The authors declare that they have no conflict of interest.

Open Access This article is licensed under a Creative Commons Attribution 4.0 International License, which permits use, sharing, adaptation, distribution and reproduction in any medium or format, as long as you give appropriate credit to the original author(s) and the source, provide a link to the Creative Commons licence, and indicate if changes were made. The images or other third party material in this article are included in the article's Creative Commons licence, unless indicated otherwise in a credit line to the material. If material is not included in the article's Creative Commons licence and your intended use is not permitted by statutory regulation or exceeds the permitted use, you will need to obtain permission 
directly from the copyright holder. To view a copy of this licence, visit http://creativecommons.org/ licenses/by/4.0/.

\section{References}

Abdu, M., Buba, A., Adamu, I., \& Muhammad, T. (2015). Drivers of financial inclusion and gender gap in Nigeria. The Empirical Econometrics and Quantitative Economics Letters (EEQEL), 4(4), 186-199.

Abel, S., Mutandwa, L., \& Le Roux, P. (2018). A review of determinants of financial inclusion. International Journal of Economic and Financial Issues, 8(3), 1-8.

Abubakar, A. M., Daneji, B. A., Muhammed, A. I., \& Chekene, I. A. B. (2020). Driving faster financial inclusion in developing nations. Technology audit and production reserves, 2/4(52), 35-40.

Al-Tamimi, H. A. H. (2009). Financial literacy and investment decisions of UAE investors. The Journal of Risk Finance.

Aliber, M. (2015). The importance of informal finance in promoting decent work among informal operators: a comparative study of Uganda and India. International Labour Office, Social Finance ProgrammeGeneva: ILO (Social Finance Working Paper, 66).

Asteriou, D., \& Hall, S. G. (2015). Applied econometrics. Macmillan International Higher Education.

Asuming, P. O., Osei-Agyei, L. G., \& Mohammed, J. I. (2019). Financial inclusion in sub-Saharan Africa: Recent trends and determinants. Journal of African Business, 20(1), 112-134.

Atakli, B. A., \& Agbenyo, W. (2020). Nexus between financial inclusion, gender and agriculture productivity in Ghana. Theoretical Economics Letters, 10(03), 545.

Atieno, R. (2001). Formal and informal institutions' lending policies and access to credit by small-scale enterprises in Kenya: an empirical assessment.

Avais, M. (2014). Financial innovation and poverty reduction. International Journal of Scientific and Research Publications, 4(1), 2250-3153.

Bajtelsmit, V. L., \& Bernasek, A. (1996). Why do women invest differently than men?. Financial Counseling and Planning, 7.

Cabeza-García, L., Del Brio, E. B., \& Oscanoa-Victorio, M. L. (2019). Female financial inclusion and its impacts on inclusive economic development. In Women's Studies International Forum (Vol. 77, p. 102300). Pergamon.

Cetindamar, D., Gupta, V. K., Karadeniz, E. E., \& Egrican, N. (2012). What the numbers tell: The impact of human, family and financial capital on women and men's entry into entrepreneurship in Turkey. Entrepreneurship \& Regional Development, 24(1-2), 29-51.

Chen, R., \& Divanbeigi, R. (2019). Can regulation promote financial inclusion?. The World Bank.

Chibba, M. (2009). Financial inclusion, poverty reduction and the millennium development goals. The European Journal of Development Research, 21(2), 213-230.

Choo, E. K., Byington, C. L., Johnson, N. L., \& Jagsi, R. (2019). From\# MeToo to\# TimesUp in health care: can a culture of accountability end inequity and harassment? The Lancet, 393(10171), 499-502.

Chowdhury, K. (1994). A structural analysis of external debt and economic growth: some evidence from selected countries in Asia and the Pacific. Applied Economics, 26(12), 1121-1131.

Demirgüç-Kunt, A., \& Klapper, L. (2012). Financial inclusion in Africa: an overview. The World Bank. Working paper 6088 .

Demirgüç-Kunt, A., \& Klapper, L. (2013). Measuring financial inclusion: explaining variation in use of financial services across and within countries. Brookings Papers on Economic Activity, 2013(1), 279-340.

Demirgüç-Kunt, A., \& Levine, R. (2008). Finance and economic opportunity. The World Bank.

Demirgüç-Kunt, A., Klapper, L., Singer, D., Ansar, S., Hess, J. (2018). Global Findex Database 2017: Measuring Financial Inclusion and the Fintech Revolution. Washington, DC: World Bank. Available at: https://openknowledge.worldbank.org/handle/10986/29510 License: CC BY 3.0 IGO."

Flory, J. A. (2018). Formal finance and informal safety nets of the poor: evidence from a savings field experiment. Journal of Development Economics, 135, 517-533. 
Ghosh, J. (2013). Microfinance and the challenge of financial inclusion for development. Cambridge journal of economics, 37(6), 1203-1219.

Hannig, A., \& Jansen, S. (2010). Financial inclusion and financial stability: Current policy issues.

Hendriks, S. (2019). The role of financial inclusion in driving women's economic empowerment. Development in Practice, 29(8), 1029-1038.

International Monetary Fund (2015a). Financing for development - revisiting the Monterrey Consensus. Washington: IMF Policy Paper. Available at: http://www.imf.org/external/np/pp/eng/2015/061515.pdf

International Monetary Fund (2015b). Nigeria - Selected Issues Paper. IMF Country Report 15/85. Washington. Available at: https://www.imf.org/external/pubs/ft/scr/2015/cr1585.pdf

Kairiza, T., Kiprono, P., \& Magadzire, V. (2017). Gender differences in financial inclusion amongst entrepreneurs in Zimbabwe. Small Business Economics, 48(1), 259-272.

Kim, D. W., Yu, J. S., \& Hassan, M. K. (2018). The influence of religion and social inequality on financial inclusion. The Singapore Economic Review, 1746003.

Kim, J. H. (2016). A study on the effect of financial inclusion on the relationship between income inequality and economic growth. Emerging Markets Finance and Trade, 52(2), 498-512.

Le, T. H., Chuc, A. T., \& Taghizadeh-Hesary, F. (2019a). Financial inclusion and its impact on financial efficiency and sustainability: Empirical evidence from Asia. Borsa Istanbul Review, 19(4), 310-322.

Le, T. T., Dang, N. D. L., Nguyen, T. D. T., Vu, T. S., \& Tran, M. D. (2019b). Determinants of financial inclusion: comparative study of Asian countries. Asian Economic and Financial Review, 9(10), 1107.

Léon, F., \& Zins, A. (2020). Regional foreign banks and financial inclusion: evidence from Africa. Economic Modelling, 84, 102-116.

Lotto, J. (2020). Understanding financial inclusion in East Africa: how does Tanzania compare?. International Journal of Finance \& Economics.

Loukoianova, M. E., Yang, Y., Guo, M. S., Hunter, M. L., Jahan, M. S., Jamaludin, M. F., \& Schauer, J. (2018). Financial Inclusion in Asia-Pacific. International Monetary Fund.

Mader, P. (2018). Contesting financial inclusion. Development and Change, 49(2), 461-483.

Manij, A. (2010). Eliminating poverty?'Financial inclusion', access to land, and gender equality in international development. The Modern Law Review, 73(6), 985-1004.

Meunier, F., Krylova, Y., \& Ramalho, R. (2017). Women's entrepreneurship: how to measure the gap between new female and male entrepreneurs?. The World Bank.

Mzobe, N. (2015). The role of education and financial inclusion in Africa: the case of selected African countries (Doctoral dissertation, Stellenbosch: Stellenbosch University).

National Financial Inclusion Strategy (2018). Central Bank of Nigeria. Available at: https://www.cbn.gov.ng/ out/2019/ccd/national\%20financial\%20inclusion\%20strategy.pdf

Olaniyi, E., \& Adeoye, B. (2016). Determinants of financial inclusion in Africa: a dynamic panel data approach. Published in: University of Mauritius Research Journal, 22(2016), 310-336.

Özşuca, E. A. (2019). Gender gap in financial inclusion: evidence from MENA. Economics and Business Letters, 8(4), 199-208.

Park, C. Y., \& Mercado, R. (2015). Financial inclusion, poverty, and income inequality in developing Asia. Asian Development Bank Economics Working Paper Series, (426).

Peng, T. C. M., Bartholomae, S., Fox, J. J., \& Cravener, G. (2007). The impact of personal finance education delivered in high school and college courses. Journal of family and economic issues, 28(2), 265-284.

Ramji, M. (2009). Financial inclusion in Gulbarga: finding usage in access. Center for Micro Finance Working Paper, 26.

Sahay, R., Čihák, M., N’Diaye, P. M. B. P., Barajas, A., Mitra, S., Kyobe, A., \& Yousefi, S. R. (2015). Financial inclusion: can it meet multiple macroeconomic goals?.

Sanderson, A., Mutandwa, L., \& Le Roux, P. (2018). A review of determinants of financial inclusion. International Journal of Economics and Financial Issues, 8(3), 1.

Sankaramuthukumar, S., \& Alamelu, K. (2012). Financial inclusion: African scenario. Insight on Africa, $4(2), 121-135$.

Sarma, M., \& Pais, J. (2011). Financial inclusion and development. Journal of international development, 23(5), 613-628.

Shafi, M., \& Medabesh, A. H. (2012). Financial inclusion in developing countries: evidences from an Indian State. International Business Research, 5(8), 116.

Sharma, A., \& Kukreja, S. (2013). An analytical study: relevance of financial inclusion for developing nations. International journal of engineering and science, 2(6), 15-20.

Sharma, D. (2016). Nexus between financial inclusion and economic growth. Journal of financial economic policy. 
Shihadeh, F. H. (2018). How individual's characteristics influence financial inclusion: evidence from MENAP. International Journal of Islamic and Middle Eastern Finance and Management.

Siddik, M. N. A. (2017). Does financial inclusion promote women empowerment? Evidence from Bangladesh. Applied Economics and Finance, 4(4), 169-177.

Singareddy, R. R., Ranjan, P., Annamalai, B., \& Chandrasekaran, S. (2019). Financial inclusion remodeling: including the excluded masses. Space and Culture India, 6(5), 178-188.

Son, T. H., Liem, N. T., Ly, H. T. N., \& Son, T. H. (2019). Understanding financial inclusion in Vietnam. Research in World Economy, 10(3), 382-390.

Susilowati, E., \& Leonnard, L. (2019). Factors influence financial inclusion: evidence from Indonesian micro data. Etikonomi, 18(1), 121-132.

Vossenberg, S. (2013). Women entrepreneurship promotion in developing countries: what explains the gender gap in entrepreneurship and how to close it. Maastricht School of Management Working Paper Series, 8(1), 1-27.

World Bank (2014). Global Financial Development Report 2014: financial inclusion. Washington: World Bank. Available at: https://openknowledge.worldbank.org/handle/10986/16238

Zhang, Q., \& Posso, A. (2019). Thinking inside the box: a closer look at financial inclusion and household income. The Journal of Development Studies, 55(7), 1616-1631.

Zins, A., \& Weill, L. (2016). The determinants of financial inclusion in Africa. Review of Development Finance, 6(1), 46-57.

Publisher's Note Springer Nature remains neutral with regard to jurisdictional claims in published maps and institutional affiliations. 